\title{
Cornual Ectopic Pregnancy in A Nigerian
}

\author{
Wilson I B Onuigbo ${ }^{1 *}$ and Gabriel C Iloabachie ${ }^{2}$ \\ 1Departments of Pathology, The University of Nigeria Teaching Hospital, Nigeria \\ 2Departments of Obstetrics \& Gynaecology, The University of Nigeria Teaching Hospital, Nigeria
}

Submission: June 21, 2018; Published: August 15, 2018

*Corresponding author: Wilson I B Onuigbo, Departments of Pathology, The University of Nigeria Teaching Hospital, Nigeria;

Email: wilson.onuigbo@gmail.com

Abstract

The cornual ectopic pregnancy is a rare ectopic gestation that occurs in the interstitial part of the uterus. In this context, single case reports are being reported worldwide. Therefore, a Nigerian case is deemed to be worthy of documentation. For instance, her age was found to be in the published range.

Keywords: Uterus; Cornu; Ectopic; Pregnancy; Nigeria

\section{Introduction}

Cornual pregnancy is a rare variety of ectopic gestation that is located in the interstitial part of the fallopian tube. In this context, single case reports have come from India [1,2], Tunisia [3], Turkey [4,5], United Arab Republic [6], UK [7], and USA [8,9]. Accordingly, we report a classical case found among the Nigerian ethnic group called the Ibos [1-10].

\section{Case Report}

OE, a 30-year-old woman, consulted Dr Gabriel Iloabachie at the University of Nigeria Teaching Hospital, Enugu, with the complaint of irregular vaginal bleeding of a month's duration. There was associated abdominal pain for 10 days. Examination revealed the existence of cornual ectopic pregnancy. The biopsy material consisted of several irregular deeply hemorrhagic pieces. These were received by the pathologist, i.e., the corresponding author. On microscopy, the diagnostic chorionic villi were identified satisfactorily. Recovery was uneventful.

\section{Discussion}

The patient was an indigene of the Ibo Ethnic Group in Nigeria. Previous reports on their odd pregnancies were those of twin tubal pregnancy [11], and bilateral tubal pregnancies [12-14]. Elsewhere, the world's pattern was largely the same [1-9]. As regards cornual ectopic pregnancy itself, the local patient aged 30 years compares favorably with the 32 years of the Tunisian. Incidentally, younger ages were met as follows: 25 years in Turkey, 28 years in the UK and 29 years in the US. It is worth mentioning that the usual resort is to surgery. However, from the United Arab Emirates, there is the conclusion that "Cornual pregnancy can be treated successfully with methotrexate injection with minimal side effects." A curious combination is that of cornual pregnancy together with a dermoid cyst which had been detected during routine ultrasonography in the US. Our case did not show any concurrent lesion.

\section{References}

1. Varun N, Nigam A, Elahi AA, Jain A (2018) Cornual ectopic pregnancy: Laparoscopic management step by step. BMJ Case Rep doi: 10.1136/ bcr-2017-223998.

2. Atal R, Chauhan M (2016) A rare case report of ruptured cornual ectopic pregnancy. Intl J Obstet Gynaecol Res 3(7): 400-404.

3. Hamouda ES, Littooij AS, Thia EW, Ong CL (2012) A ruptured cornual ectopic pregnancy at 18 weeks' gestation: A case report. Intl J Gynecol Obstet 7(10): 34-42.

4. Birge O, Erkan MM, Ozbey EG (2015) Ruptured cornual ectopic pregnancy: Case report. Proceed Obstet Gynecol 5(3): 3.

5. Sayan CD, Tulmac OB, Dag ZO (2016) Cornual ectopic pregnancy or angular pregnancy, delayed diagnosis and treatment of a pregnancy complication: A case report. Intl J Gynecol Obstet Neonat Care 3: 63-67.

6. Albiate MAS, Ismail MK (2015) Successful treatment of cornual ectopic pregnancy with a single systemic injection of methotrexate: A case report with review of literature. Gult Med J 4(S1): S6-S12.

7. Sahoo S, Jose J, Shah N, Opemuyi I (2009) Recurrent cornual ectopic pregnancies. Gynecol Surg 6: 389-391.

8. Walid MS, Heaton RL (2010) Diagnosis and laparoscopic treatment of cornual ectopic pregnancy. Ger Med Sci 8: Doc 16.

9. Martingano D, Martingano F (2016) Intact cornual ectopic pregnancy and dermoid cyst with intraoperative rupture. J Am Osteopat Assoc 116(5): 316-319.

10. Basden GT (1966) Niger Ibos. Lond: Cass, UK. 
11. Onuigbo WIB (1976) Tubal pregnancy in Nigerian Igbos. Intl J Ferti 21(3): 186-188.

12. Onuigbo WIB, Ezugwu F (2018) More examples of bilateral simultaneous tubal ectopic pregnancy in a developing community. Gynaecol Perinatol 2(2): 261-263.
13. Onuigbo WIB, Eze JN, Okafor II (2007) Twin proneness associated with two extraordinary cases of coexistence of bilateral tubal pregnancies. J Coll Med 12: 5-7.

14. Eze JN, Obuna JA, Ejikeme BN (2012) Bilateral tubal ectopic pregnancies: A report of two cases. Ann Afr Med 11(2): 112-115.

Your next submission with Juniper Publishers
will reach you the below assets
- Quality Editorial service
- Swift Peer Review
- Reprints availability
- E-prints Service
- Manuscript Podcast for convenient understanding
- Global attainment for your research
- Manuscript accessibility in different formats
( Pdf, E-pub, Full Text, Audio)
- Unceasing customer service
Track the below URL for one-step submission
https://juniperpublishers.com/online-submission.php

